\title{
REORIENTASI NILAI-NILAI KEPEMIMPINAN LEMBAGA PENDIDIKAN ISLAM MUHAMMADIYYAH DI INDONESIA
}

\author{
Sadari \\ Institut Agama Islam ShalabuddinAl-Ayyubi (INIS A) Bekasi,arifabmikban@gmail.com \\ Robiatul Adawiyyah \\ Universitas Muhammadiyah Jakarta,wiyahdpr@gmail.com \\ Nurhidayat \\ Universitas Muhammadiyah Jakarta,nurbidayat_kd76@yahoo.co.id \\ Ummah Karimah \\ Universitas Mubammadiyah Jakarta,umm4b@yahoo.co.id
}

Diterima: 18 Februari $2019 \quad$ Direvisi 25 Juni $2019 \quad$ Diterbitkan: 30 Juni 2019

\begin{abstract}
Muhammadiyah is a community organization engaged in education and is popular in Indonesia. Muhammadiyah has been successful in the local-Javanese scope, as well as at the national level. Mubammadiyah educational institutions spread throughout the territory of Indonesia. However, as it turned out it turned out to have an impact on the emergence of two style models (gaya) related to the leadership of Mubammadiyah educational institutions, namely the leadership model which is strong and some that are weak. The first model, supported by figure figures, while the second model is the opposite. The article further analyzes how these two distinctions can emerge and what steps are important to prepare with the initial assumption that reliance on the "figure" pattern of leadership alone is relatively insufficient. Mubammadiyah managed to manage its educational institutions anchored in the figures' figures. However, as technology, information, the internet and social media develop, there is a shift in orientation patterns. Talking about Mubammadiyah means being oriented towards progress, civilization, new discoveries, for that Muhammadiyah must be more careful, so there is no counter-productive that is contrary to its initial spirit. Based on the case of the distinction between the leadership of educational institutions between the strong and the weak, this article explains how that can happen, what factors cover, as well as what actions are important to be prepared by Mubammadiyah organizations in Indonesia in order to survive amid the onslaught of both globalization or even the Indonesian people who increasingly technological literacy.
\end{abstract}

Keywords: Reorientation, Leadership, Islamic education, Muhammadiyah, Indonesia

\begin{abstract}
Abstrak
Muhammadiyah adalah organisasi masyarakat yang bergerak di bidang pendidikan dan populer di Indonesia. Muhammadiyah telah berhasil di lingkup lokal-Jawa, juga level nasional. Lembaga pendidikan Mubammadiyah tersebar di selurub wilayah Indonesia. Namun seiring berjalan ternyata berdampak pada munculnya dua model gaya (tekstur) terkait dengan kepemimpinan lembaga pendidikan Mubammadiyah, yaitu model kepemimpimpinan yang kuat dan ada yang lemah. Model pertama, ditunjang oleh figur ketokohan, sedangkan model kedua sebaliknya. Artikel menganalisis lebih jaub bagaimana dua pembedaan tersebut bisa muncul dan langkah seperti apa yang penting untuk disiapkan dengan asumsi awal bahwa kebergantungan pada pola "figur" kepemimpinan saja, relatif tidak cukup. Mubammadiyah berhasil mengelola lembaga pendidikannya berjangkar pada ketokohan figur-figurnya. Namun, seiring berkembangnya teknologi, informasi, internet dan media sosial terdapat pergeseran pola orientasi. Bicara Muhammadiyah berarti berorientasi pada kemajuan, peradaban, temuan baru, untuk itu Mubammadiyah harus bersikap lebih hati-bati, agar tidak terjadi kontra-produktifyang bertentangan dengan rub awalnya.
\end{abstract}


Berpijak pada kasus pembedaan kepemimpinan lembaga pendidikan antara yang kuat dan yang lemah, artikel ini menjelaskan bagaimana itu bisa terjadi, faktor apa sajakah yang melingkupi, serta tindakan apa yang penting untuk segera disiapkan oleh oganisasi Mubammadiyah di Indonesia supaya bisa bertaban di tengah gempuran baik globalisasi atau pun masyarakat Indonesia yang semakin melek teknologi.

Kata Kunci: Reorientasi; Kepemimpinan; Pendidikan Islam; Muhammadiyyah; Indoneisa

\section{PENDAHULUAN}

Secara umum, kepemimpinan memiliki tiga unsur penting untuk dipahami, yaitu apa atau siapa yang dipimpin, pemimpin, dan pedomannya. Seseorang yang tidak memiliki pemahaman yang baik atas tiga unsur tersebut akan sulit baginya untuk mengatur suatu organisasi atau lembaga. Pemimpin yang baik akan berusaha tidak saja mempelajari pedomanpedoman dalam memimpin, tetapi juga berani meluangkan waktunya untuk mempelajari apa atau siapa yang dipimpin.

Dalam kasus Muhammadiyah, seseorang yang dipercaya menjadi pemimpin di dalamnya penting sama sekali untuk tahu tentang Muhammadiyah, arahnya, pemahaman, kepentingan, sifat, dan tujuan. Darinya, penulis merasa penting untuk memulai artikel ini dengan memaparkan terlebih dulu beberapa poin tersebut, ${ }^{1}$ antara lain:

Pertama, pemahaman bahwa

Muhammadiyah mengandaikan setiap warganya untuk menjadikan Alquran dan as-Sunnah sebagai landasan dari apa pun yang mereka lakukan. Maksud dari apa pun di sini barangkali bisa dipetakan secara umum menjadi dua ranah: privat dan publik. Ranah privat mencakup sejauh mana masyarakat Muhammadiyah selalu berupaya untuk bersikap adil sejak dalam pikirannya dan tindakan mereka dengan keluarga kecilnya. Adapun ranah publik memuat mulai dari bagaiamana mereka berorganisasi, berbisnis, mengembangkan keilmuan, kebudayaan, teknologi, seni, dan semacamnya. Satu lagi, di dalamnya juga meliputi upaya untuk selalu menjadi contoh yang baik untuk orang lain.

1 Asymuni Abdurrahman, et.al, Pedoman Hidup Islam Warga Muhammadiyyah, cet.ke-4 (Yogyakarta: Suara Muhammadiyah, 2002), 3-6.
Kedua, Landasan dan Sumber bahwa Muhammadiyah dalam hal yang paling dasar, landasan dan sumber pemikiran serta aktivisme Muhammadiyah adalah Alquran dan as-Sunnah. Setelah itu ada beberapa sumber lain, antara lain matan keyakinan dan cita-cita hidup Muhammadiyah, muqaddimah Anggaran Dasar Muhammadiyah, khittah perjuangan Muhammadiyah, dan hasil-hasil keputusan Majelis Tarjih.

Ketiga, Kepentingan bahwa dalam hal kepentingan, seperti layaknya organisasi pada umumnya, Muhammadiyah berorientasi pada kepentingan bersama. Kemudian, karena kepentingan ini berkaitan erat dengan pedoman hidup warga Muhammadiyah, maka itu bersifat lentur atau sesuai dengan perkembangan situasi dan kondisi.

Mengenai hal ini, artikel ini mengutip buku Asymuni Abdurrahman, Pedoman Hidup Islam Warga Muhammadiyah, yang menjelaskan tentang keadaan seperti apa sajakah misalnya yang penting untuk dipertimbangkan Muhammadiyah berkenaan dengan pedoman dan kepentingan organisasi, yakni: Perubahan iklim sosial-politik nasional yang berdampak nyata bagi kehidupan masyarakat Indonesia tak terkecuali warga Muhammadiyah, kemudian semakin populernya gaya berpikir yang pragmatis yang berporos pada hanya nilai guna, materialistis dengan kepentingan materi sebagai satu-satunya pijakan, dan hedonism yang menyituasikan kesenangan sebagai poros, kemudian masih merebaknya budaya asing yang semakin diminati masyarakat (penetrasi kebudayaan), semakin beragamnya kebudayaan 
yang disodorkan sebagai akibat dari globalisasi (multikulturalisme), dan semacamnya. ${ }^{2}$

Keempat, Sifat bahwa sifat yang dimaksud di sini adalah sesuatu yang melekat dalam poinpoin utama Muhammadiyah yang penting bagi warganya untuk senantiasa mencoba membumikannya, adalah sebagai berikut: Memuat ihwal penting, mendasar, dalam bentuk acuan nilai dan norma; Bersifat pengayaan yaitu memberi beragam khazanah untuk keefektifan baik roh atau pun perilaku; Aktual atau memiliki keterkaitan dengan tuntutan dan kepentingan kehidupan sehari-hari; Memberikan arah bagi tindakan individu maupaun kolektif dengan menjadikan pola "suri teladan" sebagai pertimbangan penting; Ideal yakni mampu menjadi panduan umum untuk kehidupan seharihari yang bersifat mendasar; Rabbani dalam arti mengandung ajaran-ajaran dan pesan-pesan yang dampak praktisnya jatuh kesalehan sosial atau pun digital dan Taisir maksudnya panduan yang mudah dipahami dan dipraktikkan oleh setiap muslim khususnya warga Muhammadiyah

Kelima, Tujunnya adalah menuju masyarakat Muhammadiyah yang bersuka cita dalam memberi teladan yang baik dan menjadi bagian dari agenda mewujudkan masyarakat Islam yang sebenar-benarnya baik di level individu atau pun kolektif. Untuk melihat kondisi perkembangan Muhammadiyah, artikel ini akan menjelaskan beberapa sekolah-sekolah atau lembaga-lembaga pendidikan yang telah dirintis oleh Muhammadiyah.

\section{SEKOLAH MUHAMMADIYAH}

\section{Historitas Kelembagaan}

Lembaga pendidikan Muhammadiyah untuk pertama kalinya didirikan oleh Ahmad Dahlan (1869-1923) di Jogjakarat pada permulaan abad ke-20, persisnya tahun $1012(1330 \mathrm{H}){ }^{3}$ Muhammadiyah merupakan Gerakan Islam,

2 Asymuni Abdurrahman, et.al, Pedoman Hidup Islam Warga Muhammadiyyah, cet.ke-4 (Yogyakarta: Suara Muhammadiyah, 2002).

${ }^{3}$ Syamsul Anwar, Studi Hukum Islam Kontemporer, cet. Ke-1 (Jakarta : RM Books, 2007), 313.
Dakwah Amar Makruf Nahi Munkar, dan Tajdid yang menjadikan Alquran dan as-Sunnah sebagai sumbernya. ${ }^{4}$ Kala itu, seperti banyak sekolah pada mulanya, ia hanya memiliki sepuluh siswa dengan beberapa materi. Materi agama diampu langsung oleh Ahmad Dahlan, sedangkan materi lainnya dipegang oleh teman-teman Ahmad Dahlan yang bersedia membantu. Untuk materi ilmu umum, Ahmad Dahlan meminta bantuan pada salah satu guru sekolah pemerintah.

Seturut bergulirnya waktu, sekolah tersebut berkembang dan akhirnya menelurkan beberapa sekolah lainnya yang masih dalam satu lembaga. Sampai pada tahun 1923 tercatat ada beberapa sekolah Muhammadiyah yang telah terdaftar, yaitu sebagai berikut: ${ }^{5}$

Pertama, Yogyakarta, yakni: Satu "HIS met de Qur'an" dengan 150 murid dan enam (6) orang guru, Empat "Vervolgschool" dengan 794 orang murid dan sebelas (11) orang guru, Satu Madrasah sore dengan 84 orang murid dan tiga (3) orang guru, dan Satu Sekolah Guru Islam (Kweekschool Islam) dengan lima puluh enam (56) orang murid dan delapan (8) orang guru.

Kedua, Jakarta, yakni: Satu "HIS met de Qur'an" dengan 128 orang murid dan empat (4) orang guru.

Ketiga, Surakarta, yakni: Satu "Vervolgschool" dengan delapan puluh lima (85) orang murid dan empat (4) orang guru.

Keempat, Surabaya, yakni: Satu "HIS met de Qur'an" dengan empat puluh sembilan (49) orang murid dan dua (2) orang guru, dan Satu "Vervolgschool" dengan 112 orang murid dan dua (2) orang guru.

4 Deliar Noer, Modernist Muslim Movement ind Indonesia 1900-1942 (London/New York: Oxford University Press, 1973), 73; Abuseri Dimyati, et.al, ed.'Sejarah Muhammadiyah Bagian Pertama 1912-1923", naskah ini diperbanyak dalam fotokopi (Yogyakarta: Pimpinan Pusat Muhammadiyah Majelis Pustaka, 1993), 28; Mulkhan, Pemikiran K.H. Dablan dan Mubammadiyah dalam Perspektif Perubahan Sosial (Jakarta: Bumi Aksara, 1990), 3, 27.

${ }^{5}$ Sumarsono Mestoko, et.al, Pendidikan di Indonesia dari Jaman ke Jaman, cet.ke-2 (Jakarta: Balai Pustaka, 1986), 258-263. 
Kelima, Pekalongan, yakni: Satu Madrasah dengan lima puluh (50) orang murid dan dua (2) orang guru. Pada akhir tahun 1938 jumlah sekolah, murid, dan gurunya yang telah terdaftar adalah sebagai berikut: Sekolah Desa (Volksschool) (SD 3 tahun) berjumlah 216 buah, Standaardschool SD 5 tahun berjumlah 84 buah, HIS (SD 7 tahun), Schakelschool kolah Peralihan) berjumlah 166 buah, Madrasah Ibtidaiyah (pertama) berjumlah 415 buah, Jumlah murid sampai pada angka 60182, dan Jumlah guru sampai pada angka 2066.

Catatan ini belum termasuk beberapa buah Kweekschool Muhammadiyah yang terdapat di Yogyakarta, Surakarta, dan beberapa tempat lain. Itu tidak termasuk pula MULO-HIK yang berdiri di Yogyakarta dan Surakarta serta Algemeene Mid-e School (AMS) di Betawi.

Dari data di atas, orang bisa mengamati bagaimana perkembangan sekolah Muhammadiyah tidak saja dari level jumlah siswa dan sekolah, tetapi juga jumlah kota atau pun desa tempat lembaga pendidikan Muhammadiyah berdiri. Ketika pada tahun 1950 Departemen Agama RI menyelenggarakan Sekolah pendidikan Guru Agama, maka Muhammadiyah hadir dengan PGAP dan PGAA atau PGA 6 tahun yang didirikan untuk mencetak guru-guru agama yang semakin ke sini semakin banyak dibutuhkan.

Selain sekolah buat pendidikan guru agama, Muhammadiyah juga tidak luput untuk memperhatikan perguruan tinggi atau universitas. Perguruan tinggu awal yang didirikan Muhammadiyah adalah FKIP di Yogyakarta. Kemudian disusul didirikannya Universitas Muhammadiyah Yogyakarta (UMY). Pada tahun 1950 Muhammadiyah juga mendirikan Akademi khusus di bidang Dakwah yang pada akhirnya digabung di UMY.

Ini terjadi tidak saja di Yogyakarta, tetapi juga di beberapa kota lain seperti Aceh, Surabaya, Kediri, Surakarta, Magelang, Purworejo, dan Ponorogo. Di Surakarta misalnya, di situ dibangun Institut Agama Islam Adiyah (IAIM) yang juga memiliki cabang di tiga kota terakhir.
Menurut data yang dimiliki Pimpinan Pusat Muhammadiyah, Majelis Pendidikan dan Pengajaran, pada akhir tahun 1961, keadaan Perguruan Muhammadiyah adalah sebagai berikut:

Majelis Pendidikan dan Pengajaran

\begin{tabular}{|c|c|c|}
\hline No & Jenis sekolah & Jumlah \\
\hline 1 & $\begin{array}{l}\text { Sekolah Dasar dan } \\
\text { Ibtidaiyah }\end{array}$ & 4.689 \\
\hline 2 & SLTP dan SLTA termasuk PGAP & 607 \\
\hline 3 & $\begin{array}{l}\text { Fakultas Keguruan dan Ilmu } \\
\text { Pendidikan }\end{array}$ & 4 \\
\hline 4 & Akademi Tabligh & 1 \\
\hline
\end{tabular}

Keadaan Perguruan Muhammadiyah

\begin{tabular}{|c|l|c|}
\hline No & \multicolumn{1}{|c|}{ Pelajar dan Guru } & Jumlah \\
\hline \hline 1 & Pelajar laki-laki & 150.766 \\
\hline 2 & Pelajar perempuan & 118.629 \\
\hline 3 & Guru laki-laki & 833 \\
\hline 4 & Guru perempuan & 1.832 \\
\hline
\end{tabular}

Perguruan Mubammadiyah dan Subsidi

Muhammadiyah pada jaman penjajahan Belanda bersedia menerima bantuan keuangan atau subsidi dari pemerintah Hindia Belanda bagi amal usahanya seperti Rumah Sakit dan Sekolah. Ini berlandaskan pada prinsip bahwa bahwa keuangan atau subsidi sebenarnya berasal dari rakyat, sehingga ketika dipakai untuk rakyat maka tidaklah menjadi persoalan atau malah begitulah yang harus terjadi.

Alasan lainnya jatuh pada kenyataan bahwa masyarakat Katolik dan Protestan yang notabene minoritas di Indonesia juga mendapatkan layanan pendidikan Muhammadiyah. Belanda adalah negara yang kepercayaannya memuat dua tersebut, sehingga adalah keselarasan ketika Muhammadiyah menerima dana bantuan dari Belanda untuk optimalisasi pendidikan di Indonesia. Jumlah lembaga pendidikan yang menerima subsidi pada tahun 1938 bisa diamati sebagai berikut:

\section{Lembaga Pendidikan Penerima Subsidi}

\begin{tabular}{|c|c|c|}
\hline No & Nama Lembaga & Jumlah \\
\hline$\overline{1}$ & "Inheems MULO" & $\overline{1} 1$ \\
\hline 2 & $\begin{array}{ll}\text { "HOLLANDS } & \text { INLANDSE } \\
\text { SCHOOL" (HIS) } & \\
\end{array}$ & 4 \\
\hline 3 & "Schakel School" & 21 \\
\hline 4 & "Vervolg School" & 95 \\
\hline & Total & 120 \\
\hline
\end{tabular}


Akan tetapi, meski Muhammadiyah menerima subsidi, ini bukan berarti Muhammadiyah bergantung sama sekali pada subsidi. Ada yang lebih penting daripada subsidi bagi Muhammadiyah, yakni kemampuan pribadi, kemauan, dan darma bakti umat Islam serta rakyat Indonesia secara umum. Dengan ungkapan lain, bicara sumber dana, Muhammadiyah juga mengandalkan pada donasi dari warga Muhammadiyah, di samping pengelolan bisnisnya sendiri. Terlepas dari ihwal sumber dana, di bawah ini penulis cantumkan jumlah sekolah yang berada di bawah naungan Muhammadiyah di seluruh Indonesia tahun 1975.

\section{Jumlah Sekolah-Sekolah Muhammadiyah} Seluruh Indonesia Tahun $1975^{6}$

\begin{tabular}{|c|l|c|c|c|}
\hline \multirow{2}{*}{ No } & \multirow{2}{*}{ Nama Wilayah } & \multicolumn{3}{|c|}{ Jumlah } \\
\cline { 3 - 5 } & & Sekolah & Murid & Guru \\
\hline \hline 1 & Aceh & 65 & 9462 & 564 \\
\hline 2 & Sumatera Utara & 238 & 33295 & 1485 \\
\hline 3 & Sumatera Selatan & 164 & 22861 & 1086 \\
\hline 4 & Sumatera Barat & 304 & 1652 & 105 \\
\hline 5 & Riau/Pekan Baru & 164 & 17057 & 1032 \\
\hline 6 & Lampung & 160 & 19938 & 1188 \\
\hline 7 & Bengkulu & 78 & $/ 9327$ & 844 \\
\hline 8 & Jambi & 41 & 4040 & 280 \\
\hline 9 & DKI Jaya & 117 & 35149 & 1506 \\
\hline 10 & Jawa Barat & 41 & 5990 & 343 \\
\hline 11 & Jawa Tengah & 185 & 28868 & 1535 \\
\hline 12 & Jawa Timur & 709 & 137450 & 7297 \\
\hline 13 & Yogyakarta & 313 & 68978 & 4482 \\
\hline 14 & Nusa Tenggara Barat & 10 & 1567 & 135 \\
\hline 15 & Kalimantan Barat & 7 & 591 & 52 \\
\hline 16 & Kalimantan Timur & 6 & 466 & 43 \\
\hline 17 & Kalimantan Selatan & 12 & 1075 & 61 \\
\hline 18 & Sulawesi Utara & 9 & 722 & 30 \\
\hline 19 & Sulawesi Selatan & 158 & 19017 & 1498 \\
\hline 20 & Bali & 4 & 864 & 47 \\
\hline
\end{tabular}

\section{Keterangan :}

1. Data yang masuk hanya 20 Wilayah

2. Data yang belum masuk ada 20 Wilayah

3. Data ditulis berdasarkan laporan Wilayahwilayah tahun 1975

\section{MENGENAL KEPEMIMPINAN DALAM MUHAMMADIYAH}

Sebagaimana terekam dalam Muktamar Muhammadiyah yang mengusung tema "Satu

${ }^{6}$ Sumarsono Mestoko, et.al, Pendidikan di Indonesia dari Jaman ke Jaman, cet.ke-2 (Jakarta: Balai Pustaka, 1986), 261-263.
Abad Muhammadiyah, Gerak Melintas Zaman Dakwah dan Tajdid Menuju Peradaban Utama”, seseorang bisa mengetahui betapa perjalanan Muhammadiyah tidak lepas dari pasang-surut. Ia ibarat roda yang digerakkan oleh sistem yang cukup teratur sehingga membuatnya kadang naik, kadang terpuruk, dan ketika di posisi bawah tidak ada nama lain yang digaungkan di dalamnya melainkan peran beberapa sosok di level kepemimpinannya. Oleh karenanya, wajar ketika pola kepemimpinan di Muhammadiyah banyak mendapatkan sorotan baik dari aras internal atau pun eksternal. Itu pun dari semua tingkatan: mulai dari ranting, cabang, daerah, wilayah, hingga pusat.

Selain sosok dalam kepemimpinan, Muhammadiyah juga memiliki sistem organisasi yang cukup rapi. Pola kepemimpinan yang efektif dan didukung sistem organisasi yang rapi tentu tidak akan melahirkan apa pun melainkan sebuah organisasi yang efektif. Namun, lagi-lagi, kendati begitu, zaman bergerak. Teknologi berkembang. Masyarakat berbenah dan sebagainya. Walhasil, pencapaian di muka tetap perlu untuk dikritik dan lantas diperbarui lagi sesuai kebutuhan zaman. Kembali ke level sosok, dilihat dari latar belakang, tokoh-tokoh di Muhammadiyah telah mengalami pergeseran. Pada mulanya, banyak dari mereka berasal dari kalangan ulama, yaitu mereka yang memiliki perhatian lebih ke ilmu-ilmu agama. Namun, dalam kurun sepuluh sampai sebelas tahun belakangan, tokoh-tokoh tersebut mulai beragam: tidak saja dari ulama. Ada sebagian dari tokoh berasal dari pendidikan umum dan bahkan pebisnis murni.

Semakin beragamnya latar belakang pemimpin di tubuh Muhammadiyah beriringan dengan upaya Muhammadiyah untuk tidak saja fokus pada gerakah dakwah, tetapi juga amal usaha. Amal usaha yang penulis maksud di sini tidak lain adalah badan usaha yang meliputi panti asuhan, balai pengobatan, rumah sakit, dan lembaga pendidikan. Khusus pada lembaga pendidikan, itu memuat mulai dari Taman KanakKanak (TK), Pesantren, sampai Perguruan 
Tinggi. Masih tentang badan usaha adalah juga mengenai masjid, musalla, koperasi, dan lembaga filantropi lainnya. Pergerakan Muhammadiyah di bidang badan usah seperti ini tentu bukan hadir tanpa adanya sosok pemimpin yang mampu mengurus semuanya secara proporsional. Dengan ungkapan lain, pencapaian Muhammad sementara ini di bidang badan usaha adalah cermin bagaimana kepemimpinan yang ada dalam tubuh Muhammadiyah.

Adapun mengenai Muktamar, ini lebih tepatnya disebut sebagai evaluasi, sehingga seperti apa pun posisi Muhammadiyah, evaluasi harus selalu ada. Satu ini berguna untuk menjaga kestabilan, dan dua untuk mencari celah di mana Muhammadiyah harus berbenah. Pada Muktamar di Yogyakarta, acara tersebut melahirkan apa itu yang disebut sebagai pentingnya merancang "tim" pemimpin yang kolaboratif. Jika sebelumnya perhatian yang ditekankan dalam kepemimpinan adalah ke individu, maka pasca-Muktamar tersebut diharapkan perhatian itu beralih ke skala kolektif, tim. Selain itu, satu hal lagi yang penting untuk diperhatikan adalah bagaimana para pemimpin Muhammadiyah tidak mengabaikan aspek kesejarahan Muhammadiyah itu sendiri. Konkretnya, ketika sedang dalam masa mempertimbangkan kebijakan tertentu menyangkut Muhammadiyah, para pemimpin diandaikan sama sekali untuk menimbang situasi historis Muhammadiyah yang didirikan Ahmad Dahlan sekitar satu abad silam.

Maksud lain dari tim adalah tentang sinergi antara senior dan junior, antara yang tua dan yang muda. Salah satu yang penting untuk dibenahi Muhammadiyah adalah bagaimana ia bisa menyinergikan angkatan muda dan angkatan tua. Bagaimana ia bisa mengatur kepemimpinan yang tidak saja didominasi oleh kalangan tua, tetapi juga muda, sehingga antara keduanya bisa seimbang. Satu sisi, ini berguna untuk regerasi, sedangkan pada sisi lainnya penting sebagai sebentuk kepercayaan orang tua pada anaknya di samping ide-ide yang muncul dari kalangan muda tidak jarang lebih kontekstual dan baru ketimbang yang angkatan tua. Pendeknya, bicara sinergi, sebenarnya seseorang juga sedang bicara tentang kekuatan, kecepatan, dan potensi kerja.

Lebih jauh, ada dua hal secara umum yang seorang pemimpin dirasa perlu untuk memperhatikannya, termasuk pemimpin Muhammadiyah, yakni teladan dan berpandangan luas plus objektif. Teladan lebih pada bagaimana seorang pemimpin harus berhati-hati dalam setiap tindakannya. Keselarasan antara apa yang diungkapkan, dipikirkan, dan dilakukan menjadi isu sensitif di level ini. Jika pemimpin berhasil untuk menyinergikan ketiganya, maka di waktu bersamaan teman-teman yang dipimpinnya akan secara otomatis akan segan dengannya dan di titik inilah peran penggerak seorang pemimpin bersemayam. Istilah "pemimpin adalah penggerak" tidak lain merupakan efek dari sejauh mana ia mampu menjadi teladan.

Berpandangan luas dan objektif lebih pada bagaimana seorang pemimpin menyikapi berbagai persoalan yang ada dalam tubuh organisasi. Kemampuan seperti ini memungkinkan seseorang untuk menyelesaikan segala persoalan dengan solusi yang efektif. Sebaliknya, jika seorang pemimpin tidak dibekali kemampuan tersebut, persoalan kecil pun akan susah diselesaikan dan malah biasanya yang terjadi malah salah penanganan. Problem kecil ketika cara merespons-nya salah, maka justru akan menimbulkan persoalan yang lebih besar. Ibarat mobil dengan satu ban belakang terperosok di selokan yang penanganannya dengan ditarik menggunakan mobil lain-bukan malah mengangkat satu ban yang terjebak tersebut-maka yang ada malah mobilnya terbelah jadi dua. Bagian tengahnya patah. Masalah sebenarnya kecil, tapi penanganannya salah, alhasil hasilnya semakin buruk. Berpandangan luas dan objektif membantu seorang pemimpin untuk merespons persoalan secara baik dan efektif.

Adapun di level masyarakat, dinamika sosial, pemimpin Muhammadiyah diidealkan untuk tidak saja memberi masukan kepada 
masyarakat, tetapi juga melakukan pemberdayaan. Ini berkelindan dengan badan usaha Muhammadiyah yang usai dijelaskan sebelumnya. Pemimpin Muhammadiyah sebisa mungkin penting untuk membentuk suatu badan usaha yang inklusif, melibatkan masyarakat secara umum, dan sejenisnya.

Sampai di sini, penulis bisa memetakan tugas pemimpin Muhammadiyah menjadi dua, yakni internal dan eksternal. Internal meliputi tugas untuk menyinergikan antara apa yang dipikirkan, diungkapkan, dan dilakukan, tugas untuk mengatur dirinya sendiri hingga menjadi teladan yang efektif, dan tugas untuk mampu menyelesaikan persoalan dalam tubuh Muhammadiyah secara efektif. Adapun eksternal lebih pada bagaimana sosok pemimpin Muhammadiyah berperan penting dalam pembangungan ekonomi umat dan membuka lapangan pekerjaan, disamping itu pemimpin Muhammadiyah juga diharapak secara terusmenerus menumbuhkan semangat gerakan Muhammadiyah dan mendorong dinamisasi masyarakat, ${ }^{7}$ misalnya Muhammadiyah melaksanakan program-program sosial persyarikatan ini menyangkut pendidikan, pelayanan kesehatan, dan pengembangan masyarakat. ${ }^{8}$

\section{MENJELANG SATU ABAD: PENDIDIKAN MUHAMMADIYAH (MASIH) MISKIN LEADERSHIP SKILL}

Seorang guru Muhammadiyah di desa kecil selalu menyampaikan kata-kata tersebut di atas-pendidikan Muhammadiyah miskin kemampuan memimpin-secara berulang-ulang layaknya Ahmad Dahlan menyampaikan al-Maun kepada muridnya sampai berkali-kali. Artinya, pendidikan kepemimpinan bagi guru tersebut sangat penting. Tidak hanya bagi guru tersebut

7 Nakamura, "The Reformist Ideology of Muhammadiyah, "Makalah disajikan dlam diskusi panel dengan tema "Focus on Islam, "Research ZSchool of Pacific Studies, ANU, 9 November 1979, 13.

${ }^{8}$ Syamsul Anwar, Studi Hukum Islam Kontemporer, cet. Ke-1 (Jakarta : RM Books, 2007), 318. tapi untuk masa depan peradaban dan bangsa. Tapi lambat laun semakin sedikit yang menyadari hal ini.

Di era ketika siswa bisa mengakses bebas informasi melalui internet, satu hal yang penting diperhatikan bagi pendidik adalah kreativitas. Untuk konteks saat ini, pendidik tidak cukup hanya dengan menyampaikan informasi pada siswa. Mereka tidak cukup pula hanya dengan memberi siswa buku bacaan dan kemudian menyuruh mereka membaca. Pasalnya, semua itu bisa dengan mudah dilakukan para siswa di luar sekolah dan bahkan dengan situasi yang jauh lebih layak ketimbang di sekolah, sehingga ketika sudah demikian apa yang menjadi poin plus sekolah dan pendidik. Satu jawaban: kreativitas.

Untuk menjaga sekolah tetap menarik dan berbeda dari internet adalah sebisa mungkin menyediakan agen-agen pendidik yang kreatif. Sayangnya, sejauh penelusuran penulis, di banyak sekolah Muhammadiyah, penulis hanya menemukan sedikit pendidik yang kreatif.

Kreativitas di sini bisa diukur paling tidak dari dua hal, yaitu memantik siswa untuk berpikir dan kemasan. Pertama lebih kepada bagaimana pendidik sebisa mungkin menjelaskan suatu isu dengan retorika yang membuat penasaran. Ini bisa dilakukan dengan tidak begitu saja membeberkan semua informasi kepada siswa. Gaya seperti ini baik untuk melatih daya kritis siswa. Adapun kedua lebih pada daya mengolah data atau informasi.

Bagaimana misalnya pendidik penting untuk mengajarkan pada siswa untuk tidak saja menerima informasi yang mereka dapatkan, dari mana pun itu, tetapi mengolahnya dulu. Daya pengolahan data seperti inilah yang barangkali bisa menjaga distingsi sekolah Muhammadiyah dari internet. Pendidik diharapkan bisa tampil lebih kreatif dan memikirkan hal-hal tersebut.

Termasuk dalam model kemasan adalah mengenai pendidik sebagai inspirator. Ketika menjelaskan isu tertentu, pendidik diandaikan untuk bisa menyampaikannya seolah siswa terlibat dalam persoalan yang sedang mereka 
diskusikan. Ini bisa dilakukan melalui contohcontoh.

Saat temanya adalah sosiologi umpamanya, sebisa mungkin pendidik di sekolah Muhammadiyah bisa memberi contoh yang memadukan antara nilai Muhammadiyah dan situasi siswa dalam era informasi hari ini. sebagai ilustrasinya adalah bagaimana siswa bisa menggunakan akun Muhammadiyah garis lucu, konten-kontennya, untuk membuat lelucon dengan teman sebangkunya-dengan asumsi, humor adalah cara paling efektif mencairkan keadaan di kala tegang. Akan tetapi, meski demikian, yang tidak kalah penting dari ini yaitu perilaku pendidik sendiri.

Maksud dari pendidik itu inspiratory adalah lebih pada sejauh mana mereka berhasil memberi contoh pada siswa mereka dalam banyak hal. Memecahkan persoalan misalnya. Jadi, ketika siswa sedang berhadapan dengan pendidik, mereka tidak melihat sesosok yang hanya bisa berbicara teori, tapi praktiknya nol besar.

Dengan ungkapan lain, pendidik di kalangan Muhammadiyah hari ini kurang memberikan perhatiannya pada jiwa kepemimpinan. Akibatnya, dalam mengajar, mereka tidak berbeda jauh dengan internet yang sekadar memberi informasi tanpa harus ada pengelolaan dan interaksi yang cukup berarti dengan para siswa. Ini belum lagi ketika dikaitkan dengan adanya tendensi lain dari pendidik Muhammadiyah seperti kepentingan PNS, politik, bisnis, dan sebagainya. Tendensi seperti ini secara umum tidaklah terlalu bermasalah selama tugas utama mereka tidak terkalahkan.

Pendidik boleh melakukan kolaborasi antara bisnis dan mendidik di sekolah Muhammadiyah, tetapi tidak mengabaikan poinpoin kepemimpinannya sebagai pendidik. Di bawah ini penulis memetakan beberapa hal mengapa jiwa kepemimpinan di Muhammadiyah rendah, antara lain:

1. Orientasi sekolah Muhammadiyah kebanyakan tidak berjalan menuju ke arah kepemimpinan.
2. Pendidik bukanlah seseorang yang ditugaskan untuk terlibat secara aktif di bidang kepemimpinan atau organisasi sehingga pola pikirnya sebatas mengajar dalam arti sekadar memberi informasi.

3. Para jajaran sekolah Muhammadiyah yang masih menganggap sebelah mata organisasi pelajar Muhammadiyah (OPM), padahal itu penting untuk memupuk jiwa kepemimpinan.

Berhenti sejenak di sini, siapa pun bisa mengerti mengapa ide untuk mengintegrasikan jiwa kepemimpinan dan jiwa pendidik di sekolah Muhammadiyah menjadi penting.

Pertama, sebab selama ini, di level sekolahnya, Muhammadiyah kurang memberi perhatian pada jiwa dan rasa kepemimpinansehingga jika ini dipertahankan akan berbahaya bagi masa depan sekolah mengetahui saat ini segalanya bisa diperoleh melalui internet-dan kedua bagaimana pun kepemimpinan penting bagi pendidik untuk mengelola siswa supaya lebih kritis dalam mengelola data dan informasi, tidak sekadar membebek ${ }^{9}$ dan menerima apa adanya. Yang penulis maksudkan di sini adalah mengenai mental: mental belajar.

\section{REFLEKSI: HASIL SEBUAH PENELITIAN TERHADAP LEMBAGA PENDIDIKAN MUHAMMADIYAH}

Sebagai titik pijak, penulis akan mengutip hasil riset Noor Jehhan, Implementasi Manajemen Berbasis Sekolah (MBS) dalam Meningkatkan Kualitas Lembaga Pendidikan Islam (Studi kasus di SD Muhammadiyah IV Malang). ${ }^{10}$ Ada beberapa poin yang perlu penulis diskusikan di sini, antara lain:

Pertama, implementasi MBS di SD Muhammadiyah IV telah dirintis sejak tahun 2003. Dengan menggandeng UNICEF, sistem ini menelurkan beberapa tahapan antara lain; (a)

${ }^{9}$ Istilah membebek, meminjam dari buku karya, Mohammad Hatta, Ajaran Marx atau Kepintaran Sang Murid Membeo, cet. Ke-1 (Jakarta : Bulan Bintang, 1975).

10 Noor Jehhan, Implementasi Manajemen Berbasis Sekolah dalam Meningkatkan Kualitas Lembaga Pendidikan Islam (Studi Kasus di SD Muhammadiyah IV Malang), tesis Program Studi Ilmu Keislaman Konsentrasi Pendidikan Islam Program Pascasarjana Iain Sunan Ampel Surabaya, 2008. 
sosialisasi, (b) pelatihan, (c) perumusan visi, misi, dan tujuan pendidikan, (d) identifikasi terhadap fungsi-fungsi yang diperlukan untuk mencapai sasaran sekolah berdasarkan standar berlaku, (e) evaluasi dan analisis kelembagaan antara kondisi nyata dan standar yang akan dicapai, (f) merencanakan pengembangan kelembagaan (sekolah), (g) melaksanakan rencana pengembangan sekolah, dan (h) melakukan pemantauan dan evaluasi. Selama 5 tahun ini, melalui sistem tersebut, sekolah telah banyak merasakan manfaat dari otonomi pengelolaan. Beberapa darinya adalah mulai adanya birokrasi yang semakin singkat, pengelolaan yang efektif dan efisien, kegiatan belajar-mengajar yang kreatif plus variatif, adanya transparansi, dan masyarakat yang tidak enggan untuk berpartisipasi.

Kedua, sistem MBS di SD Muhammadiyah IV berdampak pula pada kualitas dan layanan pendidik. Ini mencakup lima hal, yaitu prestasi akademik dan non-akademik yang menggembirakan, pola belajar yang efisien, tumbuhnya jiwa kepemimpinan yang visioner, kinerja meningkat seiring baiknya profesionalitas pendidik, dan masyarakat yang partisipatif.

Ketiga, dari beberapa diskusi di muka, penulis bisa menaruh beberapa poin yang berpengaruh dalam keberhasilan program MBS, sebagai berikut:

\section{Kepemimpinan yang efektif}

Salah satu yang paling bertanggungjawab atas berjalannya program di sekolah tersebut adalah kepala sekolah. Boleh dibilang, kepala sekolah berperan aktif, memberi teladan, dan sejenisnya sehingga para guru bersemangat untuk mengoptimalkan tugasnya masing-masing. Di waktu bersamaan pun, energi positif yang disalurkan kepala sekolah ke para guru, tersalurkan pula ke para siswa.

\section{$\underline{\text { Tata nilai }}$}

Selain itu, ada pula tata nilai. Di sekolah yang bersangkutan, ada nilai yang secara sangat halus dan rapi dielaborasikan dengan iklim sekolah. Seseorang bisa merasakan suatu nuansa yang berkarakter di dalamnya. Nilai-nilai tersebut memuat nilai ibadah, nilai jihad, nilai fastabiq alkhairat, disiplin, dan nilai keteladanan.

Ibadah berkenaan dengan niat untuk menjadikan segala yang dilakukan di sekolah tersebut sebagai ibadah, baik dari sisi siswa, guru, kepala sekolah, hingga petugas lapangan. Nilai jihad lebih kepada rasa bertanggungjawab. Segala sesuatu jika dilandasi dengan mental untuk tanggung jawab, maka hasilnya tidak akan mengecewakan. Nilai ketiga menyangkut ihwa semangat belajar, semangat bekerja, dan semacamnya. Nilai terakhir beriringan dengan nilai ketiga.

\section{Jaringan (networking)}

Jaringan yang penulis maksud adalah kerjasama yang dilakukan SD Muhammadiyah IV dengan berbagai pihak. Mulai dari kerjasama finansial sampai konsep kelembagaan, mereka lakukan dengan berbasiskan tata nilai di muka.

$$
\text { Seperti halnya gading, SD }
$$

Muhammadiyah IV tentu juga memiliki beberapa keretakan atau kendala. Di bawah ini adalah beberapa kendala yang dihadapinya, antara lain: Masih terbatasnya sarana prasarana sekolah dalam penyelenggaraan program sekolah seperti ruang kelas, ruang lab komputer, dan perangkatnya; dan Adanya sebagian kecil orang tua siswa yang kurang responsif dengan program sekolah mengingat orangtua siswa SD Muhammadiyah IV sangatlah heterogen baik dari status sosial maupun latar belakang pendidikan.

Dari hasil penelitian tentang implementasi MBS di SD Muhammadiyah IV Malang, peneliti kemudian memberikan beberapa saran sebagai berikut:

Pertama, untuk pengelola pendidikan, Melalui otonomi pendidikan, seharusnya sekolah lebih bisa bebas untuk berkreasi dan berlatih mandiri. Maksud dari dua istilah tersebut akan lebih mudah dipahami ketika disejajarkan dengan adanya kompetisi yang semakin mengerikan di era globalisasi. Walhasil, sekolah yang tidak mau berpikir lebih keras lagi, lebih kreatif lagi, maka 
tidak ada masa depan kecuali pemakaman dirinya. Pasalnya, saat ini musuh terberatnya adalah internet berikut segala dampaknya pada dunia pendidikan dan sosial kemasyarakatan. Lebih jelasnya, di titik ini, pemegang kebijakan sekolah Muhammadiyah dituntut untuk selalu memikirkan mau dibawa ke manakah sekolah tempat ia mengabdi mengetahui masyarakat telah jauh bergeser. Jadi, ini murni tentang reorientasi visi, misi, dan strategi secara berkelanjutan.

Kedua, untuk pendidik, Secara eksplisit ada empat 4 kompetensi yang perlu dimiliki dan dikembangkan oleh guru-sebagaimana diamanatkan undang-undang sistem pendidikan nasional (UUSPN) bab IV pasal 28 ayat 3 tahun 2005 tentang kompetensi guru-yakni kompetensi paedagogik, kompetensi kepribadian, kompetensi profesional, dan kompetensi sosial. Karenanya, guru dituntut untuk selalu kreatif dan inovatif demi masa depan sekolah.

Ketiga, untuk praktisi pendidikan, Mengenai praktisi ini, penulis lebih mengarahkannya pada kemampuan untuk memperbaiki dan selalu memperbaiki tujuan pendidikan supaya selalu selaras dengan kebutuhan siswa-guru secara khusus dan masyarakat secara umum. Tujuan tersebut selanjutnya dirumuskan dalam model pendidikan yang aplicable, partisipatif, dan sarana-prasarana yang relevan dengan tujuan utama sekolah.

\section{KESIMPULAN}

Dari semua data yang sudah disampaikan, sudah semestinya Muhammadiyah melakukan reorientasi serta pengembangan sistem pendidikan. Muhammadiyah penting untuk tidak saja fokus pada layanan pendidikan, tetapi juga memikirkan dan selalu memikirkan pemikiranpemikiran yang lebih kekinian, baru, barik dari level keislaman, ilmu pengetahuan, dan peradaban. Muhammadiyah penting pula untuk melampui posisinya selama ini yang sebatas lembaga pendidikan pelengkap yang diselenggarakan pemerintah dan bersiap menuju pola pendidikan yang berbasiskan sistem mutakhir plus mandiri.

Pada akhirnya hal konkret yang Muhammadiyah perlu mempertimbangkannya adalah kepentingan untuk merancang suatu sekolah berbasis internasional (SBI), pendidikan yang mampi menelurkan lulusan profesional, pendidikan yang memiliki akses terhadap dimensi-dimensi global dengan tanpa harus menyingkirkan aspek kearifan lokal yang selama ini menjadi landasan pijak Muhammadiyah. Konsep "pembaruan" yang selama ini melekat dalam tubuh Muhammadiyah patut untuk senantiasa dijaga dengan merenungkan dan selalu merenungkan sistem pendidikan sekaligus kepemimpinan-dengan model tim, salah satunya-yang efektif.

\section{DAFTAR KEPUSTAKAAN}

Abdurrahman, Asymuni, et.al, Pedoman Hidup Islam Warga Muhammadiyyah, cet.ke-4, Yogyakarta: Suara Muhammadiyah, 2002.

Anwar, Syamsul, Studi Hukum Islam Kontemporer, cet. Ke-1, Jakarta: RM Books, 2007.

Arifin, Imron, Peningkatan Kualitas Pendidikan Madrasah Melalui Inovasi Manajemen Pendidikan; Pendekatan Madrasah-Based Management dalam Pelatihan Kepala Madrasah Se-Jawa Timur oleh STAIN Malang, 17 oktober 1999.

Azra, Azyumard, Jaringan Ulama Timur Tengah dan Kepulauan Nusantara Abad XVII dan XVIII, Bandung, Mizan, 1994.

..........., Pendidikan Islam; Tradisi dan Modernisasi Menuju Milenium Baru. Jakarta: Logos Wacana ilmu, 1999.

Bogdan, R,C. dan Biklen, S.K, Qualitative Research for Education, an Introduction to Theory and Methods, Boston: Allyn and Bacon Inc, 1982.

Departemen Pendidikan Nasional Direktorat Jenderal Pendidikan Dasar dan Menengah Direktorat Sekolah Lanjutan Tingkat Pertama, Manajemen Peningkatan Mutu Berbasis Sekolah -Buku I. Jakarta: 2001.

Dimyati, Abuseri, et.al, ed. 'Sejarah Muhammadiyah Bagian Pertama 1912- 
1923", naskah ini diperbanyak dalam fotokopi, Yogyakarta: Pimpinan Pusat Muhammadiyah Majelis Pustaka, 1993.

Duhou, Ibtisam Abu, School Based Management (Manajemen Berbasis Sekolah). Jakarta: Logos Wacana Ilmu, 2002.

Faisal, Sanapiah, Format-Format Penelitian Sosial, Jakarta: Manajemen PT. Grafindo Persada, 2001.

Fajar, Malik, Visi Pembaharuan Pendidikan Islam, Jakarta: CV. Alfa Grafikatama, 1998.

Fattah, Nanang, Manajemen Berbasis Sekolab; Strategi Pemberdayaan Sekolah dalam rangka Peningkatan Mutu dan Kemandirian Sekolah. Bandung: Penerbit Andira, 2000.

Faure, Edgar, "Pendidikan dan Hari Depan Ummat Manusia" dalam Pendidikan: Kegelisahan Sepanjang Zaman, Ed. Sindhunata, Yogyakarta: Kanisius, 2001.

Firdaus, Akhol, Sesat Nalar Manajemen Berbasis Sekolah (makalah), 2003.

Gorton, Richard A, School Administration. Iowa: W.M.C. Brown Company Publishers, 1976.

Huberman, A. Michael dan Miles, B. Matthew B, "Data Management and Analysis Methods" dalam Handbook of Qualitative Research ed. Denzin, K. Norman dan Lincoln, S. Yvonna S. London: Sage Publication, 1994.

Jehhan, Noor, implementasi manajemen berbasis sekolah dalam meningkatkan kualitas lembaga pendidikan islam (studi kasus di sd mubammadiyah iv malang), tesis Program Studi Ilmu Keislaman Konsentrasi Pendidikan Islam Program Pascasarjana Iain Sunan Ampel Surabaya, 2008.

Jerome, S. Arcaro, Pendididkan Berbasis Mutu; Prinsip-prinsip perumusan dan Tata langkah Penerapan, Yogyakarta: Pustaka pelajar, 2005.

Maksum, Madrasah: Sejarah dan Perkembangannya, Jakarta: Logos Wacana Ilmu, 1999.

Mestoko, Sumarsono, et.al, Pendidikan di Indonesia dari Jaman ke Jaman, cet.ke-2, Jakarta: Balai Pustaka, 1986.

Moleong, Lexy J, Metodologi Penelitian Kualitatif, Bandung: PT. Remaja Rosdakarya, 2000.

Morhman, Susan Albers, et.al, School-Based Management; Organizing for High
Perfomance, San Francisco: Josey Bass, 1994.

Muhadjir, Noeng, Metodologi Penelitian Kualitatif, Yogyakarta: Rake Sarasin, 2003.

Mulkhan, Pemikiran K.H. Dablan dan Muhammadiyah dalam Perspektif Perubahan Sosial, Jakarta: Bumi Aksara, 1990.

Mulyasa, E, Manajemen Berbasis Sekolab; Konsep, Strategi dan Implementasi. Bandung: PT.Remaja Rosdakarya, 2003.

Noer, Deliar, Modernist Muslim Movement ind Indonesia 1900-1942, London/New York: Oxford University Press, 1973.

Nakamura, "The Reformist Ideology of Muhammadiyah, "Makalah disajikan dlam diskusi panel dengan tema "Focus on Islam, "Research ZSchool of Pacific Studies, ANU, 9 November 1979, 13.

Nurkolis, Manajemen Berbasisi Sekolah: Teori, Model dan Aplikasi, Jakarta: Grasindo, 2003.

Poster, Cyril, Gerakan Menciptakan Sekolah Unggul. Jakarta: Lembaga Indonesia Adidaya, 2000.

Rahim, Husni, Arah Baru Pendidikan Islam di Indonesia. Jakarta: Logos Wacana Ilmu, 2001.

Sallis, Edward, Total Quality Management, Terj. Riyadi, Ahmad Ali, Yogyakarta: Ircisod, 2006.

Spradly, J.P, Metode Etnograf, Terj. Elizabeth, Misbah Zukfa, Yogyakarta: Tiara Wacana, t.t.

Steenbrink, Karel, Pesantren, Madrasah, Sekolah; Pendidikan Islam dalam Kurun Modern, Jakarta: LP3ES: Jakarta, 1994.

Strauss, Anselm dan Corbin, Juliet, Basics of Qualitative Research; Grounded Theory, Procedures and Tehniques, London: Sage Publication, 1990.

Subakir, Supriyono dan Sapari, Ahmad, Manajemen Berbasis Sekolab; Upaya Peningkatan Mutu Pendidikan Dasar Melalui Pemberdayaan Masyarakat, Otonomi Sekolah dan Pembelajaran Aktif, Kreatif dan Menyenagkan (PAKEM)-Rintisan di Mojokerto, Surabaya: Penerbit Anggota IKAPI Cabang Jatim, 2001.

Sutopo, H.B, "Pengumpulan dan Pengolahan Data dalam Penelitian Kualitatif" dalam Metodologi Penelitian Kualitatif: Tinjauan Teoritis dan Praktis, Ed. Masykuri Bakri, 
Malang: Lembaga Penelitian Universitas Islam Malang dan Visi Press, 2003.

Suyanto, "Memahami Visi dan Misi Mendikbud Baru" dalam Kompas, Jum'at 24 April 1998.

Wahid, Abdul, "Manajemen Berbasis Madrasah; Ikhtiar Menuju Madrasah yang Mandiri" dalam Dinamika Pesantren dan Madrasah, Ed. Ismail dkk. Yogyakarta: Pustaka Pelajar, 2002.

World Bank, Education in Indonesia; from Crisis to Recovery, Jakarta: tp, 1998.

Yulk, A. Gray, Kepemimpinan dan Organisasi, Jakarta: Prenthallindo, 1998.

Yunus, Mahmud, Sejarah Pendidikan Islam di Indonesia, cet. ke-2, Jakarta: Mutiara, 1977.

, Pendidikan Islam di Indonesia, Jakarta: Mutiara, 1979.

Hatta, Mohammad, Ajaran Marx atau Kepintaran Sang Murid Membeo, cet. Ke-1, Jakarta : Bulan Bintang, 1975. 